Atmos. Chem. Phys., 13, 9321-9335, 2013

www.atmos-chem-phys.net/13/9321/2013/

doi:10.5194/acp-13-9321-2013

(c) Author(s) 2013. CC Attribution 3.0 License.

\title{
Global ozone-CO correlations from OMI and AIRS: constraints on tropospheric ozone sources
}

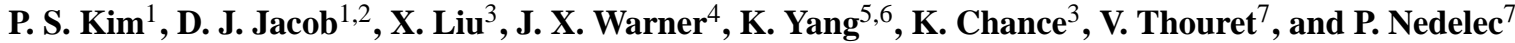 \\ ${ }^{1}$ Harvard University, Department of Earth and Planetary Sciences, Cambridge, MA, USA \\ ${ }^{2}$ Harvard University, School of Engineering and Applied Sciences, Cambridge, MA, USA \\ ${ }^{3}$ Harvard-Smithsonian Center for Astrophysics, Cambridge, MA, USA \\ ${ }^{4}$ University of Maryland, College Park, College of Computer, Mathematical and Natural Science, \\ College Park, MD, USA \\ ${ }^{5}$ University of Maryland, College Park, Department of Atmospheric and Oceanic Science, MD, USA \\ ${ }^{6}$ NASA Goddard Space Flight Center, Greenbelt, MD, USA \\ ${ }^{7}$ Laboratoire d'Aerologie, UMR5560, CNRS and Universite de Toulouse, Toulouse, France
}

Correspondence to: P. S. Kim (kim68@fas.harvard.edu)

Received: 7 March 2013 - Published in Atmos. Chem. Phys. Discuss.: 3 April 2013

Revised: 28 July 2013 - Accepted: 10 August 2013 - Published: 17 September 2013

\begin{abstract}
We present a global data set of free tropospheric ozone-CO correlations with $2^{\circ} \times 2.5^{\circ}$ spatial resolution from the Ozone Monitoring Instrument (OMI) and Atmospheric Infrared Sounder (AIRS) satellite instruments for each season of 2008. OMI and AIRS have near-daily global coverage of ozone and $\mathrm{CO}$ respectively and observe coincident scenes with similar vertical sensitivities. The resulting ozone-CO correlations are highly statistically significant (positive or negative) in most regions of the world, and are less noisy than previous satellite-based studies that used sparser data. Comparison with ozone-CO correlations and regression slopes $\left(d \mathrm{O}_{3} / d \mathrm{CO}\right)$ from MOZAIC (Measurements of OZone, water vapour, carbon monoxide and nitrogen oxides by in-service AIrbus airCraft) aircraft profiles shows good general agreement. We interpret the observed ozone-CO correlations with the GEOS (Goddard Earth Observing System)-Chem chemical transport model to infer constraints on ozone sources. Driving GEOS-Chem with different meteorological fields generally shows consistent ozone-CO correlation patterns, except in some tropical regions where the correlations are strongly sensitive to model transport error associated with deep convection. GEOS-Chem reproduces the general structure of the observed ozone-CO correlations and regression slopes, although there are some large regional discrepancies. We examine the model sensitivity of $d \mathrm{O}_{3} / d \mathrm{CO}$ to different ozone
\end{abstract}

sources (combustion, biosphere, stratosphere, and lightning $\mathrm{NO}_{\mathrm{x}}$ ) by correlating the ozone change from that source to $\mathrm{CO}$ from the standard simulation. The model reproduces the observed positive $d \mathrm{O}_{3} / d \mathrm{CO}$ in the extratropical Northern Hemisphere in spring-summer, driven by combustion sources. Stratospheric influence there is also associated with a positive $d \mathrm{O}_{3} / d \mathrm{CO}$ because of the interweaving of stratospheric downwelling with continental outflow. The wellknown ozone maximum over the tropical South Atlantic is associated with negative $d \mathrm{O}_{3} / d \mathrm{CO}$ in the observations; this feature is reproduced in GEOS-Chem and supports a dominant contribution from lightning to the ozone maximum. A major model discrepancy is found over the northeastern $\mathrm{Pa}$ cific in summer-fall where $d \mathrm{O}_{3} / d \mathrm{CO}$ is positive in the observations but negative in the model, for all ozone sources. We suggest that this reflects a model overestimate of lightning at northern midlatitudes combined with an underestimate of the East Asian CO source.

\section{Introduction}

Tropospheric ozone is produced by the photochemical oxidation of carbon monoxide (CO), methane $\left(\mathrm{CH}_{4}\right)$, and nonmethane volatile organic compounds (NMVOCs) in the presence of nitrogen oxides $\left(\mathrm{NO}_{\mathrm{x}} \equiv \mathrm{NO}+\mathrm{NO}_{2}\right)$. It is a potent 
greenhouse gas and harmful surface air pollutant, with implications for climate, human health, and agricultural productivity (IPCC, 2007). Current global models can capture the observed large-scale spatial and seasonal patterns of ozone concentrations but there is large uncertainty in the driving factors, as reflected by the large differences between models in ozone production and loss rates (Wild, 2007; Wu et al., 2007) and in source contributions (Fiore et al., 2009). We present here a high-density global satellite database of ozone-CO correlations using data from the Ozone Monitoring Instrument (OMI; Levelt et al., 2006) and the Atmospheric Infrared Sounder (AIRS; Aumann et al., 2003), and explore its value for constraining our understanding of the factors controlling ozone.

Many studies have used ozone-CO correlations derived from in situ observations to constrain ozone sources and transport. $\mathrm{CO}$ is emitted from incomplete combustion and has an atmospheric lifetime of a few months against oxidation. Fishman and Seiler (1983) first used the sign of the ozone-CO correlation in aircraft observations to distinguish between ozone produced photochemically in the troposphere (positive) and transported down from the stratosphere (negative). Positive surface air correlations observed in aged pollution and biomass burning plumes have been used to infer ozone production efficiencies (OPEs) and continental export (Parrish et al., 1993; Chin et al., 1994; Hirsch et al., 1996; Mao and Talbot, 2004; Jaffe and Wigder, 2012). Negative correlations may result from ozone chemical loss and surface deposition (Cardenas et al., 1998; Parrish et al., 1998; Harris et al., 2000). Observations from aircraft and remote mountain sites show that ozone-CO correlations extend into the free troposphere and on intercontinental scales, although they then reflect mixing of air masses as well as chemistry (Andreae et al., 1994; Mauzerall et al., 1998; Zahn et al., 2002; Honrath et al., 2004; Hudman et al., 2007). Interleaving of stratospheric intrusions with polluted continental outflow can complicate the fine-scale correlations in the free troposphere (Parrish et al., 2000; Nowak et al., 2004; Price et al., 2004; Liang et al., 2007).

Coincident satellite observations providing global coverage of ozone and $\mathrm{CO}$ have become available over the past decade from the NASA A-Train constellation. The vertical resolution of satellite retrievals is typically limited to $1-2$ pieces of information in the troposphere. Zhang et al. (2006) first demonstrated that ozone-CO correlations could be derived from Tropospheric Emission Spectrometer (TES) retrievals of the mid-troposphere (Beer et al., 2001). Hegarty et al. $(2009,2010)$ examined ozone-CO correlations from TES grouped by the predominant synoptic circulation patterns over North America, and found a well-defined positive relationship in continental export in spring-summer. Voulgarakis et al. (2010) used TES data from 2005 to 2008 to derive global ozone-CO correlation statistics for DecemberJanuary and July-August, and compared to results from two global models. They concluded that a systematic underes- timate of the TES-derived ozone-CO correlations by the UKCA model was likely caused by model transport errors.

All previous ozone- $\mathrm{CO}$ correlation analyses from space have used ozone and CO satellite data from the TES instrument. A drawback is the limited coverage of TES due to lack of cross-track scanning. Individual satellite retrievals have large random error, compromising correlation analyses unless large ensembles are considered. Correlation analyses using TES have had to aggregate the data over $\sim 1000 \mathrm{~km}$ spatial domains and/or over several years. Even so, the random retrieval error is problematic when diagnosing ozoneCO correlations (Zhang et al., 2006).

In this work, we produce a new database of ozone-CO correlations from space using ozone retrievals from OMI and $\mathrm{CO}$ retrievals from AIRS. These two instruments aboard the NASA A-Train observe the same scenes with near coincidence ( $<15 \mathrm{~min})$. They use different spectral bands (OMI in the UV, AIRS in the thermal IR) but their vertical sensitivities are similar. Both provide near-daily global coverage. This allows us to calculate robust statistical relationships between ozone and $\mathrm{CO}$ with much less error and finer spatiotemporal resolution than previous satellite studies. We evaluate the resulting product with ozone-CO correlation data from MOZAIC (Measurements of OZone, water vapour, carbon monoxide and nitrogen oxides by in-service AIrbus airCraft) aircraft profiles (www.iagos.fr). Here we present global ozone-CO correlations for each season of 2008 on a $2^{\circ} \times 2.5^{\circ}$ grid, and we use the global GEOS (Goddard Earth Observing System)-Chem chemical transport model (CTM) to interpret these correlations. A subsequent paper will examine interannual variability.

\section{Data and methods}

\subsection{OMI}

The OMI instrument is onboard the NASA Aura satellite with an Equator crossing time of $\sim 13: 45$ LT. It measures solar backscatter at $270-500 \mathrm{~nm}$. The nadir footprint is $13 \mathrm{~km} \times 24 \mathrm{~km}$, with near-daily global coverage from its $2600 \mathrm{~km}$ cross-track push-broom scanner. We use the Level $2 \mathrm{G}$ product of PROFOZ ozone profile retrievals by X. Liu et al. (2010), with a few major modifications described below. This retrieval is based on the optimal estimation method of Rodgers (2000). It reports partial ozone columns for 24 layers extending from the surface to $\sim 0.1 \mathrm{hPa}$. The retrieved vertical profile of partial ozone columns, described by the vector $\hat{\boldsymbol{x}}$ can be expressed as

$\hat{\boldsymbol{x}}=\mathbf{A} \mathbf{x}+(\mathbf{I}-\mathbf{A}) \mathbf{x}_{\mathrm{a}}+\epsilon$,

where $\mathbf{A}$ is the averaging kernel matrix, $\mathbf{x}$ is the true vertical profile, $\mathbf{I}$ is the identity matrix, $\mathbf{x}_{\mathrm{a}}$ is the a priori estimate, and $\epsilon$ is the retrieval error. The averaging kernel matrix represents the sensitivity of the retrieval to the true profile. 
To speed up processing, the retrieval is done here at a nadir resolution of $52 \mathrm{~km} \times 48 \mathrm{~km}$ by averaging (co-adding) $4 / 8$ OMI UV1 (270-310 nm)/UV2 (310-330 nm) pixels. A major change to the retrieval presented by X. Liu et al. (2010) is the constraint on measurement error. Recent downward revision of the OMI measurement error (Braak, 2010), together with further reduction of this error through co-adding, results in unrealistically small observational error specification ( $\sim 0.035 \%$ at $320 \mathrm{~nm}$ under tropical clear conditions) that causes spurious variability in the retrieval. This is most likely due to other unaccounted measurement and forward modeling errors. Therefore a minimum measurement error of $0.2 \%$ in the spectral region of $300-330 \mathrm{~nm}$ is imposed. In addition, X. Liu et al. (2010) used effective $\mathrm{O}_{3}$ cross sections and performed calculations at the OMI spectral grid resolution, which causes radiance errors up to $0.2-0.6 \%$ at some wavelengths (with spectral position and magnitude errors varying with solar zenith angle). In the new algorithm, the radiative transfer calculation is done using VLIDORT (Spurr, 2006) as in X. Liu et al. (2010), but is now performed at selected wavelengths, interpolated to a fine grid of $0.05 \mathrm{~nm}$ using weighting functions, and is then convolved with OMI slit functions. This new scheme can reduce the radiance errors to typically less than $0.1 \%$.

The PROFOZ retrievals typically have $0.5-1.0$ degrees of freedom for signal (DOFS), usually peaking at 700-500 hPa. We filter out poor retrievals by requiring that the average and root mean square (RMS) fitting residuals provided by the retrieval for the UV-2 channel be less than $3 \%$ of the measurement error, and we also exclude data poleward of $60^{\circ}$ due to high solar zenith angles.

The a priori estimate for the PROFOZ retrieval uses the McPeters et al. (2007) ozone profile climatology, which depends on calendar month and latitude. This adds variability to the retrieved profiles that is not actually measured. We remove this variability as in Zhang et al. (2006) by reprocessing the OMI retrievals to use a fixed a priori profile everywhere, which we choose as the mean annual McPeters et al. (2007) profile for $30^{\circ} \mathrm{S}-30^{\circ} \mathrm{N}$.

Intercomparison of the OMI PROFOZ and TES ozone retrievals by Zhang et al. (2010) shows that the two exhibit similar geographic and seasonal variability with differences generally within \pm 10 ppbv. Validation of the OMI PROFOZ retrieval with ozonesonde profiles shows a global mean positive bias of $2.8 \mathrm{ppb}$ in the troposphere (Zhang et al., 2010), which we subtract from the retrieved values.

\subsection{AIRS}

The AIRS instrument is onboard the NASA Aqua satellite with an Equator crossing time of $\sim 13: 30$ LT. AIRS retrieves CO by observing thermal emission around the $4.7 \mu \mathrm{m}$ vibrational fundamental band. We use the Level $2 \mathrm{CO}$ profiles from the version 5 (v5) AIRS retrieval (available for download through ftp://airspar1u.ecs.nasa.gov). A detailed description of the retrieval algorithm is available in Susskind et al. (2003). We use the Support retrieval product, which includes higher resolution profiles than the Standard product, reporting CO partial columns on 100 pressure levels between 1100 and $0.016 \mathrm{hPa}$. AIRS CO retrievals typically have $\sim 0.8$ DOFS with sensitivity generally peaking between 600 and $300 \mathrm{hPa}$ (Warner et al., 2007). The AIRS a priori is a fixed vertical profile from Deeter et al. (2003) up to $10.25 \mathrm{hPa}$ and from the Air Force Geophysics Laboratory (AFGL) standard atmosphere profile above.

Validation of the AIRS v5 retrieval with aircraft vertical profiles shows a positive bias of $6-10 \%$ in the Northern Hemisphere (McMillan et al., 2011) with a larger positive bias in the Southern Hemisphere (Yurganov et al., 2008, 2010; Warner et al., 2010). To correct for this bias we scale AIRS profiles down by $10 \%$. We remove retrievals that do not have a quality flag of $\mathrm{QA}=0$ provided in the retrieval product as well as any profiles with surface temperature reported as less than $250 \mathrm{~K}$. For consistency with OMI, we limit our analysis to the daytime retrievals.

\subsection{GEOS-Chem}

We use the GEOS-Chem global CTM (version 9-01-02, http: //geos-chem.org), originally described by Bey at al. (2001) and Park et al. (2004), to interpret the observed satellite ozone-CO relationships. GEOS-Chem is driven by Goddard Earth Observing System (GEOS-5) assimilated meteorological data from the NASA Global Modeling and Assimilation Office (GMAO). The GEOS-5 meteorological data have a native horizontal resolution of $0.5^{\circ} \times 0.67^{\circ}$ with 72 vertical pressure levels and $6 \mathrm{~h}$ temporal frequency $(3 \mathrm{~h}$ for surface variables and mixing depths). We degrade the horizontal resolution to $2^{\circ} \times 2.5^{\circ}$ for input to GEOS-Chem. The model results presented here are for 2008 following a $1 \mathrm{yr}$ initialization.

Global anthropogenic emissions of $\mathrm{CO}, \mathrm{NO}_{\mathrm{x}}$, and $\mathrm{SO}_{2}$ are from the EDGAR 3.2 monthly inventory for 2000 (Olivier and Berdowski, 2001) while anthropogenic NMVOC emissions are from the RETRO monthly global inventory for 2000 (van het Bolscher et al., 2008). The default inventories are scaled for subsequent years on the basis of economic data (van Donkelaar et al., 2008) and regional overwrites are used where available. These include the US EPA NEI inventory for 2005, Asian emissions from Zhang et al. (2009) for 2006, the EMEP inventory for Europe (Vestreng and Klein, 2002) for 2005, the CAC emission inventory for Canada for 2005, and the BRAVO emission inventory for Mexico (Kuhns et al., 2003) for 1999. Global shipping emissions are from ICOADS, as implemented in GEOS-Chem by Lee et al. (2011). Global biofuel emissions are from Yevich and Logan (2003). Biomass burning emissions are from the Global Fire Emission Database version 3 (GFED3) inventory with monthly resolution (Giglio et al., 2010; van der Werf et al., 2010). Biogenic VOC emissions are from the Model of 
Emissions of Gases and Aerosols from Nature (MEGAN) inventory of Guenther et al. (2006). The present simulation also includes conversion of $\mathrm{HO}_{2}$ to $\mathrm{H}_{2} \mathrm{O}$ in aerosol particles (Mao et al., 2013).

Lightning $\mathrm{NO}_{\mathrm{x}}$ emissions are constrained by an OTD/LIS (Optical Transient Detector and Lightning Imaging Sensor) climatology of lightning flash observations from satellites as described by Sauvage et al. (2007) and Murray et al. (2012), with timing and vertical distribution determined by GEOSChem deep convection. The global lightning $\mathrm{NO}_{\mathrm{x}}$ source is $6 \mathrm{Tg} \mathrm{Na}^{-1}$ (Martin et al., 2007) with higher $\mathrm{NO}_{\mathrm{x}}$ yield per flash at northern midlatitudes compared to the tropics (Hudman et al., 2007).

Vertical profiles of ozone and $\mathrm{CO}$ in the stratosphere are simulated in GEOS-Chem using GEOS-5 transport, as in the troposphere, but with climatological production and loss rate constants. Production and loss rate constants for ozone in the stratosphere are computed locally with the Linoz algorithm of McLinden et al. (2000), while those for CO are specified on a monthly basis from the 2-D model of Schneider et al. (2000).

Previous evaluations of the ozone and $\mathrm{CO}$ simulations with OMI and AIRS by Zhang et al. (2010) and Kopacz et al. (2010) showed that GEOS-Chem is in general consistent with observations. However, several regional biases were apparent in these studies. In particular, the ozone simulation of Zhang et al. (2010) underestimated ozone in the tropics while overestimating ozone in the northern subtropics and southern midlatitudes. We will discuss these biases in the context of the present simulation below.

\subsection{Correlation statistics}

We average the individual OMI ozone and AIRS CO profile retrievals over a $2^{\circ} \times 2.5^{\circ}$ horizontal grid, based on the center of the satellite footprint, for each day of 2008. We focus on the $700-400 \mathrm{hPa}$ columns, where both instruments have maximum sensitivity. These are computed by adding the corresponding partial columns in the retrievals, with linear interpolation as necessary. For clarity of presentation, we convert the partial columns to the corresponding column mixing ratios. We compute the $700-400 \mathrm{hPa}$ DOFS by adding the corresponding elements of the diagonal of the averaging kernel matrix and remove scenes with DOFS of less than 0.1.

We compute seasonal ozone-CO correlation statistics, specifically the correlation coefficient $(r)$ and unweighted reduced-major-axis (RMA) regression slope $\left(d \mathrm{O}_{3} / d \mathrm{CO}\right)$, for the three-month time series (DJF, MAM, JJA, SON) of the ozone and $\mathrm{CO}$ mixing ratios for each grid square.

For comparison to the satellite data, we archive GEOSChem daily output at the local satellite overpass time and regrid it vertically to the instrument retrieval levels. Since GEOS-Chem has little predictive capability in the stratosphere due to the use of climatological chemical rates, we replace the simulated profiles above the tropopause with the observed profiles as in Zhang et al. (2006). The simulated ozone and $\mathrm{CO}$ profiles are then smoothed with the instrument averaging kernels to account for the measurement sensitivity. The ozone-CO statistics from GEOS-Chem are calculated using the same methodology as the satellite data described above.

Random noise in individual ozone and $\mathrm{CO}$ profile retrievals degrades the ozone-CO correlations but this can be greatly reduced by averaging (central limit theorem). The high density of OMI and AIRS observations is of considerable advantage for this purpose. After data filtering, there are typically 10-30 OMI and AIRS profiles binned daily in each $2^{\circ} \times 2.5^{\circ}$ grid square where data are available, with more profiles at lower latitudes. Tests applying random retrieval error to the GEOS-Chem profiles, as in Zhang et al. (2006), indicate little effect of retrieval noise on the simulated ozoneCO correlations from OMI and AIRS. This is in contrast to the TES results of Zhang et al. (2006) and Voulgarakis et al. (2010) where the correlations were found to be significantly degraded by that noise.

\subsection{Evaluation with MOZAIC aircraft data}

We evaluate the ozone-CO correlations and regression slopes derived from OMI/AIRS with in situ aircraft profiles over commercial airports in 2006 and 2008 from the MOZAIC program (Marenco et al., 1998 and www.iagos.fr). MOZAIC ascent/descent profiles extend up to a permanent $12 \mathrm{~km}$ limit. The profiles are vertically interpolated to the satellite retrieval grids and smoothed with the mean instrument averaging kernel matrix for the corresponding day and $2^{\circ} \times 2.5^{\circ}$ horizontal grid square. The $700-400 \mathrm{hPa}$ ozone and CO mixing ratios are then calculated for MOZAIC in the exact same manner as for the OMI/AIRS data described in Sect. 2.4. We require at least 10 MOZAIC vertical profiles with coincident satellite data at a site in a given season to derive ozone-CO correlations. This requirement is satisfied in those two years for three MOZAIC sites in Europe (Frankfurt, London, Vienna), four sites in the USA (Atlanta, Dallas, Philadelphia, Portland), two sites in Asia (Hyderabad, Tokyo), and one site in Africa (Windhoek). Only Windhoek, Namibia, has sufficient data for all four seasons.

\section{Global ozone-CO correlation patterns}

Figure 1a and $\mathrm{b}$ show global maps of the 2008 seasonal mean mixing ratios for AIRS CO and OMI ozone at 700$400 \mathrm{hPa}$. CO is highest over and downwind of combustion source regions (fossil fuel, seasonal fires). The spring maximum is primarily driven by photochemical loss of $\mathrm{CO}$ from reaction with $\mathrm{OH}$. Ozone features include the wellknown spring-summer maximum in the northern extratropics (Monks, 2000) and minimum over the tropics except for biomass burning regions and the South Atlantic (Martin et 


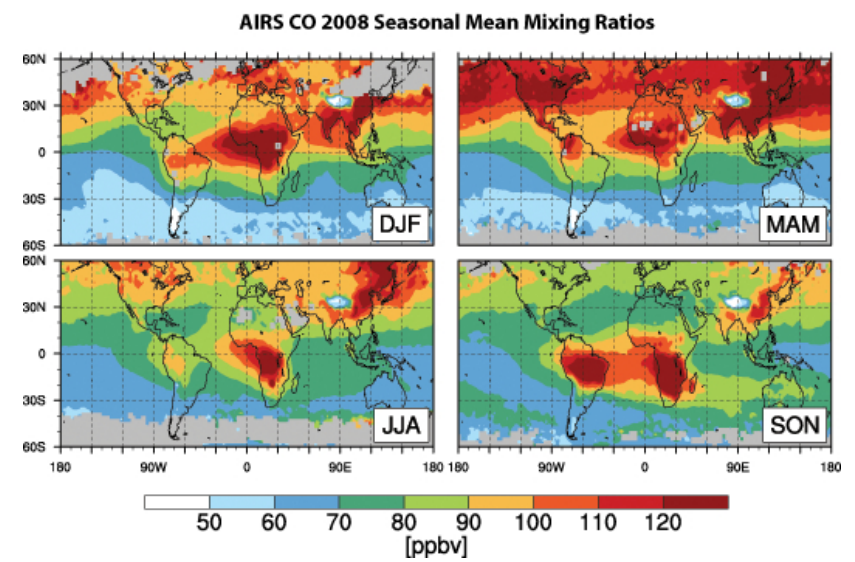

Fig. 1a. Seasonal mean AIRS CO mixing ratios at $700-400 \mathrm{hPa}$ for 2008. Data are plotted on the $2^{\circ} \times 2.5^{\circ}$ GEOS-Chem grid. Gray indicates insufficient data (see text).

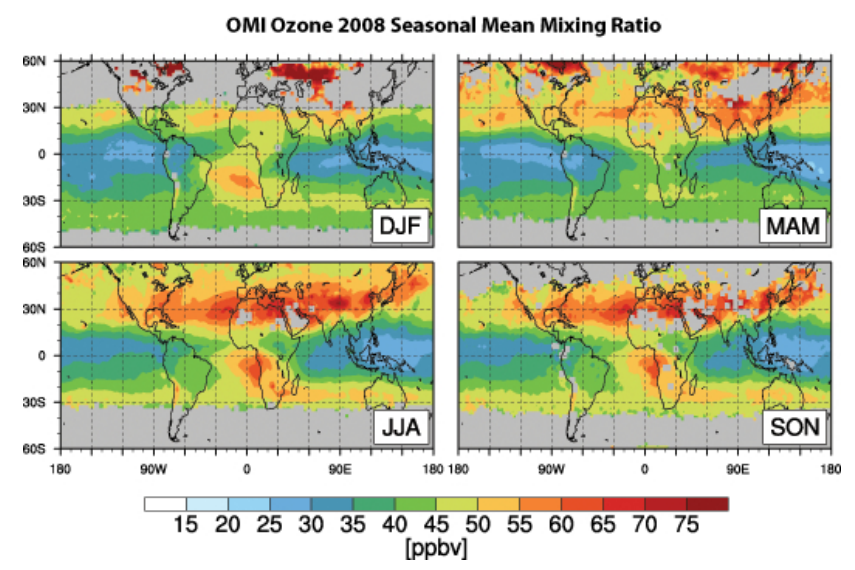

Fig. 1b. Same as Fig. 1a but for OMI ozone mixing ratios at 700 $400 \mathrm{hPa}$.

al., 2002). Ozone at southern midlatitudes peaks in winterspring, reflecting a combination of stratospheric and biomass burning influences (Zhang et al., 2010).

Comparison of Fig. 1 to the corresponding seasonal mean distributions for ozone and CO simulated by GEOS-Chem (Fig. S1a and b in the Supplement) shows that the model generally reproduces the large-scale patterns and seasonal cycles of both species. Biases in the ozone simulation are similar to those reported by Zhang et al. (2010).

Figure 2 shows the observed seasonal ozone-CO correlation coefficients and RMA regression slopes $\left(d \mathrm{O}_{3} / d \mathrm{CO}\right)$ from OMI and AIRS and compares them to the corresponding GEOS-Chem values. The correlations are in general highly statistically significant. Strong positive correlations are observed in all seasons in the northern subtropics, particularly downwind of the continents. The strongest correlations are in MAM and JJA, with $r$ exceeding 0.8 over the western Pacific. GEOS-Chem shows prominent discrepancies over Eurasia and the northeastern Pacific in JJA and SON

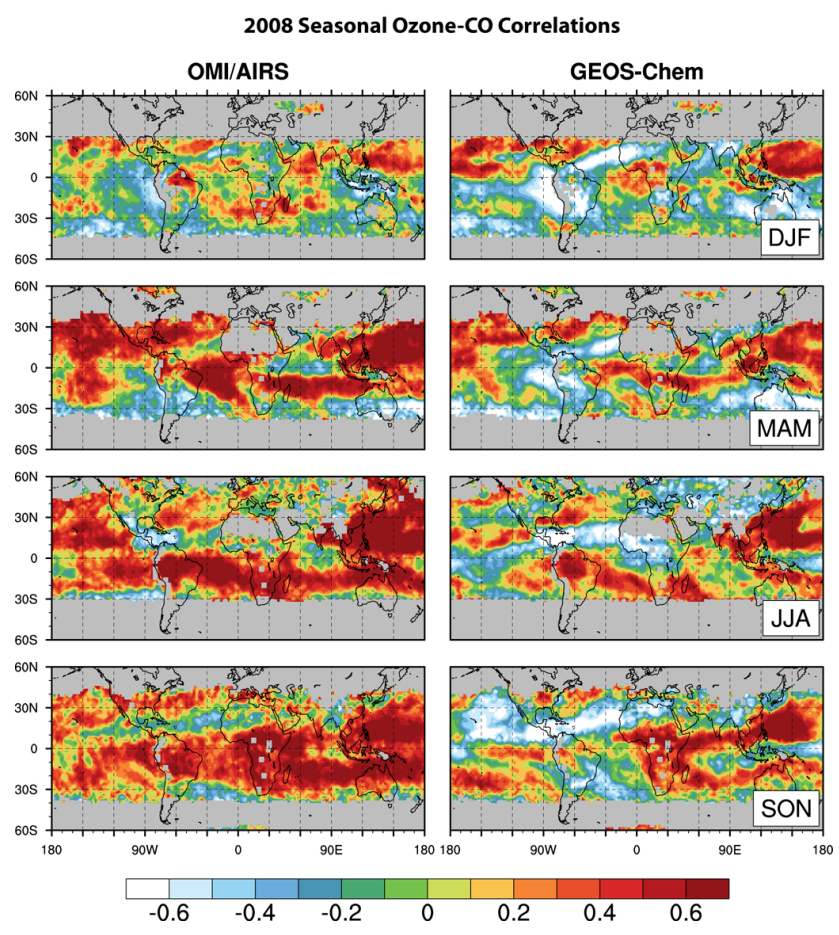

Fig. 2a. Ozone-CO correlation coefficients $(r)$ for OMI/AIRS and GEOS-Chem for each season of 2008. The correlation coefficients are computed from daily data at $700-400 \mathrm{hPa}$ on the $2^{\circ} \times 2.5^{\circ}$ GEOS-Chem grid. Gray indicates insufficient data.

where model correlations are negative. Quantitative discussion of correlations over the North Atlantic and northeastern Pacific will be presented in the next section.

Observed correlations in the tropics show positive or negative values depending on region. Positive correlations in the northern tropics appear to be an extension of the subtropics. The strongest negative correlation is over the Caribbean in JJA, with $r$ exceeding -0.7 . This reflects lightning influence as discussed below. The well-known ozone maximum over the tropical South Atlantic also features a negative correlation and this will be examined quantitatively in the next section.

The observed OMI/AIRS correlations reported here are generally consistent with previous TES results for July 2005 (Zhang et al., 2006), spring seasonal composites for the North Atlantic (Hegarty et al., 2009), and the 4 yr global July-August results (Voulgarakis et al., 2010). The higher data density from OMI/AIRS provides finer-scale information. We find regional discrepancies with the Voulgarakis et al. (2010) TES analysis for December-January, for example in the sign of $r$ over Indonesia. This may reflect interannual variability or actual inconsistency between the TES and OMI/AIRS product. We will address this issue in future work.

Figure 3 compares the OMI/AIRS RMA regression slopes $\left(d \mathrm{O}_{3} / d \mathrm{CO}\right)$ to the corresponding MOZAIC aircraft values 


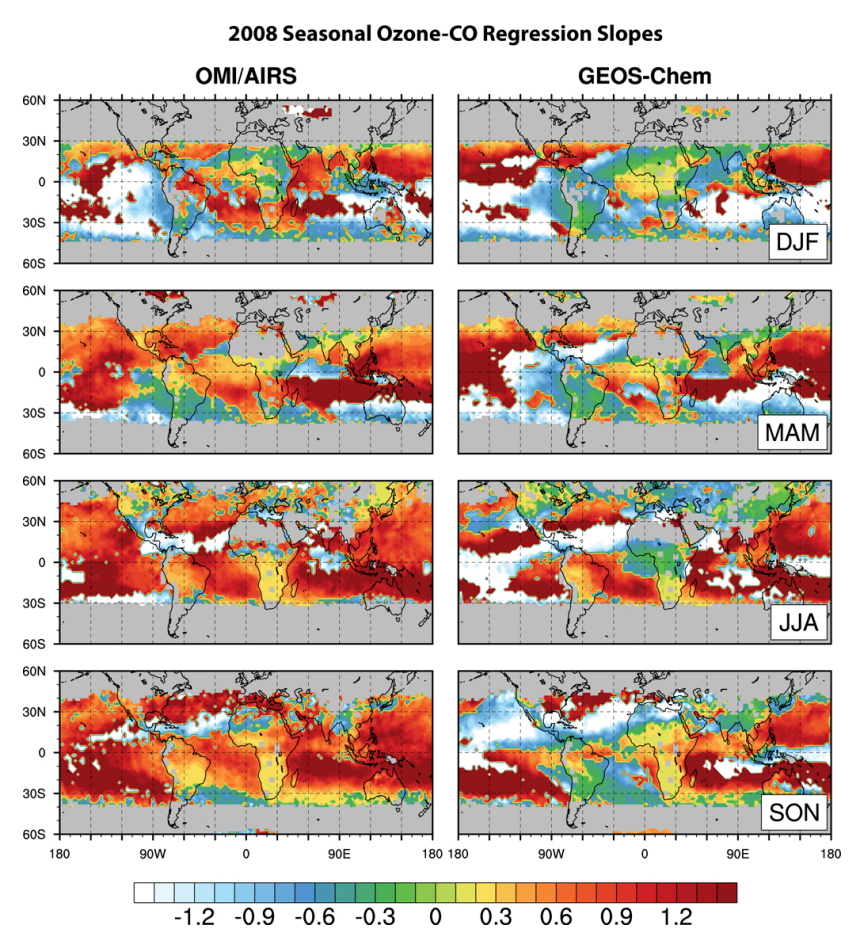

Fig. 2b. Same as Fig. 2a but for the ozone-CO RMA regression slope $\left(d \mathrm{O}_{3} / d \mathrm{CO}\right)$.

for each season of 2006 and 2008. Full statistics are in the Supplement (Table S1). The MOZAIC slopes are positive and significant in all seasons, and this is consistent with the local OMI/AIRS slopes (no MOZAIC data are available where OMI/AIRS observes negative slopes). The $r$ values from OMI/AIRS are in the same range as for MOZAIC. The slopes are strongly correlated with $r=0.63$ although $d \mathrm{O}_{3} / d \mathrm{CO}$ values from OMI/AIRS are $20 \%$ larger than from MOZAIC. The largest $d \mathrm{O}_{3} / d \mathrm{CO}$ value in both cases is over Hyderabad in SON 2008, reflecting the contrast between polluted continental air and clean maritime tropical air. The smallest $d \mathrm{O}_{3} / d \mathrm{CO}$ value in both cases (with strong correlation; Table S1) is over Namibia in JJA 2008 and is typical of biomass burning plumes (Mauzerall et al., 1998).

\section{Interpretation of the ozone-CO relationship}

Ozone-CO correlations reflect a combination of transport and chemistry. In pollution outflow mixing with a relatively clean background, the ozone- $\mathrm{CO}$ relationship gives a measure of the OPE for that pollution source region (Parrish et al., 1993; Hirsch et al., 1996). In stratospheric intrusions mixing with tropospheric air, the ozone-CO relationship reveals the stratospheric influence on ozone (Fishman and Seiler, 1983). In general, however, the relative contributions of transport and chemistry in driving the ozone-CO relationship are not obvious, especially in the free troposphere where the chemistry is relatively slow and pollution enhancements

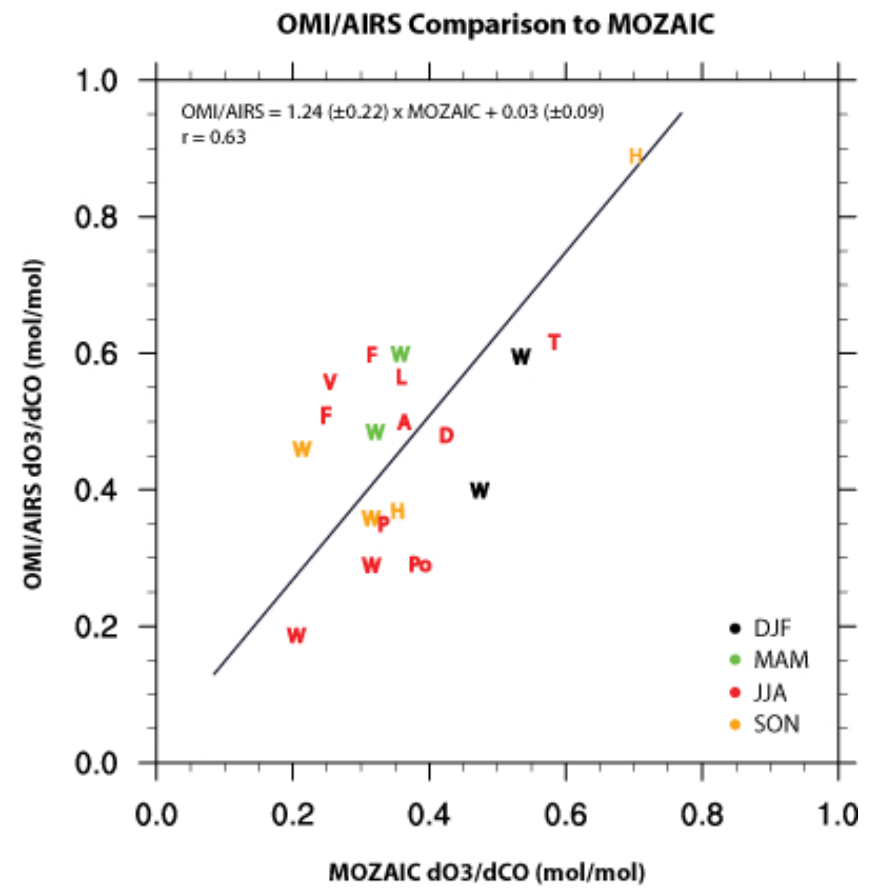

Fig. 3. Comparison of ozone-CO RMA regression slopes $\left(d \mathrm{O}_{3} / d \mathrm{CO}\right)$ at $700-400 \mathrm{hPa}$ of the MOZAIC and OMI/AIRS observations. The RMA linear fit is shown inset with bootstrap errors. Values are shown for all MOZAIC vertical profile locations with $n>10$ for individual seasons of 2006 and 2008. Complete comparison statistics are in Table S1. The station locations are W: Windhoek, Namibia; Po: Portland, USA; D: Dallas, USA; A: Atlanta, USA; P: Philadelphia, USA; L: London, UK; F: Frankfurt, Germany; V: Vienna, Austria; T: Tokyo, Japan; and H: Hyderabad, India.

are relatively weak. Previous studies for the free troposphere have highlighted how interpretation of ozone-CO correlations is complicated by mixing of combustion plumes with a variable background (Mauzerall et al., 1998) or by interleaving of stratospheric intrusions with polluted continental outflow (Parrish et al., 2000; Nowak et al., 2004; Price et al., 2004; Liang et al., 2007). These complications motivate the use of a CTM to interpret the observed ozone-CO relationships.

Two previous studies have used CTMs to interpret observed ozone-CO correlations from satellites. Zhang et al. (2008) found positive ozone-CO correlation coefficients in two transpacific pollution events in both the TES retrievals and GEOS-Chem. They interpreted the observed correlations as indicative of Asian pollution influence on ozone, since the correlation disappeared in the model in a sensitivity simulation without Asian emissions. Voulgarakis et al. (2010) conducted sensitivity simulations with perturbed emissions in the G-PUCCINI and UKCA models to examine the importance of different sources in driving the global correlation patterns. They found that emissions were important 
for changing the strength of the correlation downwind of source regions, with biomass burning in the tropics capable of changing the sign.

Here we use the GEOS-Chem CTM to interpret the OMI/AIRS ozone-CO correlations presented in Fig. 2. Our aim is to use the observed correlations as constraints on the model representation of ozone sources. This can be compromised if the simulated correlations are highly sensitive to model transport error. In that case, comparison to observed correlations would mainly serve as a convoluted test of model transport. Thus we first examine the sensitivity of the ozoneCO correlations in GEOS-Chem to model transport error, diagnose the features that appear to be robust against this transport error, and then conduct a more focused examination of the sensitivity to ozone sources for regions of particular interest.

\subsection{Sensitivity to model transport error}

We examined the impact of model transport errors on the ozone-CO relationship simulated with GEOS-Chem by comparing the standard simulation driven by GEOS-5 meteorological data to a simulation driven by the previousgeneration GEOS-4 meteorological data for the same year. Here we used 2006, the last year for which GEOS-4 data are available. GEOS-5 and GEOS-4 are very different in terms of both model physics (they use different general circulation models) and data assimilated. Previous studies have compared GEOS-5 and GEOS-4 simulations of CO (Liu et al., 2010) and $\mathrm{CO}_{2}$ (Feng et al., 2011; Parazoo et al., 2012) and shown large differences reflecting the different convective parameterizations.

Figure 4 shows ozone-CO correlations in JJA 2006 from OMI/AIRS, GEOS-Chem driven by GEOS-4, and GEOSChem driven by GEOS-5. The OMI/AIRS JJA correlations for 2006 (El Niño) are similar to the 2008 (La Niña) results shown in Fig. 2a, with slight differences over the United States and Southeast Asia. We find that the ozone-CO correlations simulated by GEOS-Chem using GEOS-5 and GEOS-4 meteorological fields generally show similar spatial patterns. The main differences are in the tropics, where GEOS-4 tends to simulate weaker negative correlations than GEOS-5.

Overall, we conclude that model transport errors can have significant regional impacts on simulated ozone-CO correlations. In some areas such as the equatorial western Pacific, this completely compromises the ability to interpret $d \mathrm{O}_{3} / d \mathrm{CO}$ in terms of ozone sources. In most regions, however, the general correlation patterns are sufficiently robust against model transport errors (at least for GEOS-5 vs. GEOS-4) that we can investigate them further to diagnose contributions from ozone sources.

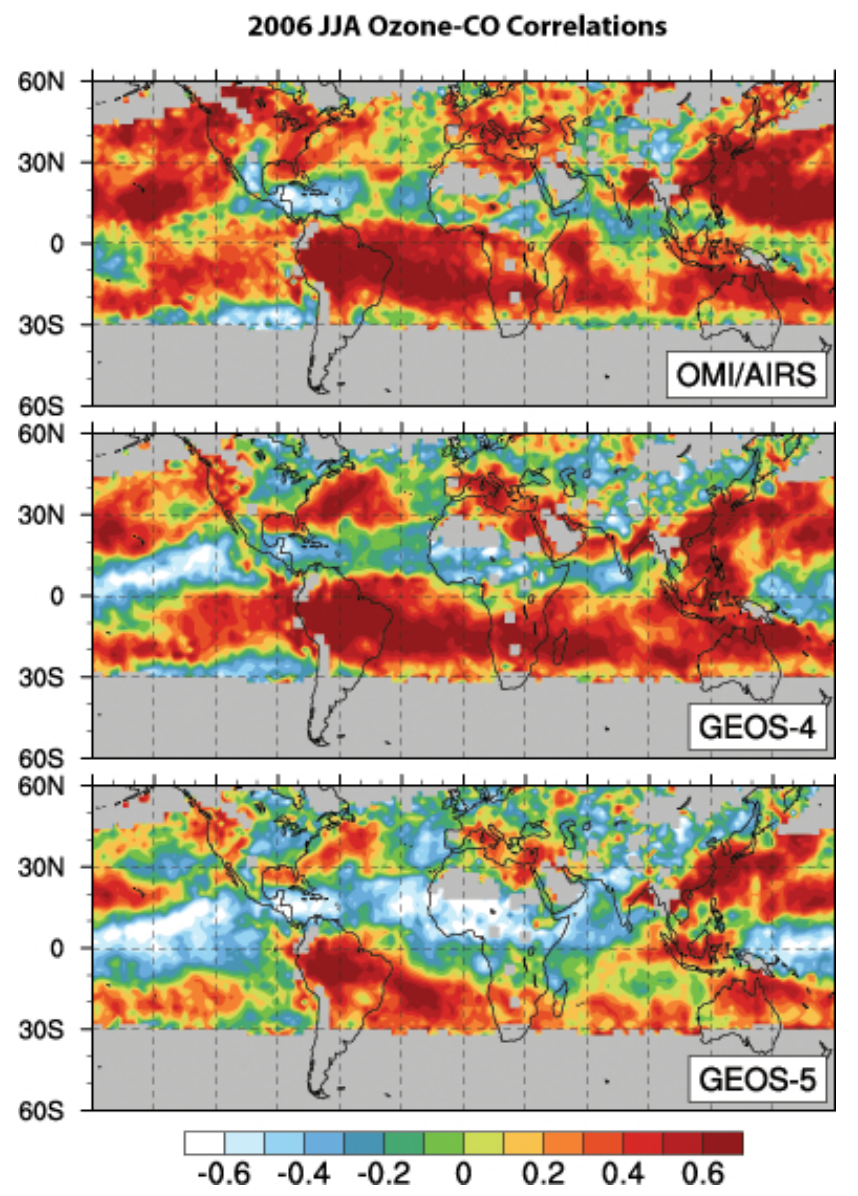

Fig. 4. Ozone-CO correlation coefficients $(r)$ at $700-400 \mathrm{hPa}$ for JJA 2006 from OMI/AIRS and from GEOS-Chem driven by GEOS4 and GEOS-5 meteorology. Gray indicates insufficient data.

\subsection{Sensitivity to ozone sources}

We now examine here whether the observed ozone-CO relationships can be used to place constraints on combustion $\left(\mathrm{NO}_{\mathrm{x}}, \mathrm{CO}, \mathrm{VOCs}\right)$, biogenic (VOCs), lightning $\left(\mathrm{NO}_{\mathrm{x}}\right)$, and stratospheric sources of ozone. All four are considered to be major sources of ozone, but their relative importance in different regions of the troposphere is uncertain (Stevenson et al., 2006; Wu et al., 2007; Terao et al., 2008; Baray et al., 2012). Starting from the standard GEOS-Chem simulation described in Sect. 2.3 and with results shown in Figs. S1 and 2, our approach is to conduct sensitivity simulations with individual sources shut off. Here we aggregate fossil fuels and biomass burning in the combustion source, with the understanding that the latter will mainly affect the tropics.

Zhang et al. (2006) and Voulgarakis et al. (2010) previously diagnosed the influence of individual sources on the ozone-CO relationship as the change in the ozone- $\mathrm{CO}$ correlation or slope $\left(d \mathrm{O}_{3} / d \mathrm{CO}\right)$ between their standard CTM simulation and a sensitivity simulation with that source shut off. However, this does not provide a proper measure of the 
Ozone-CO Relationship for $70^{\circ} \mathrm{W}, 38^{\circ} \mathrm{N}$
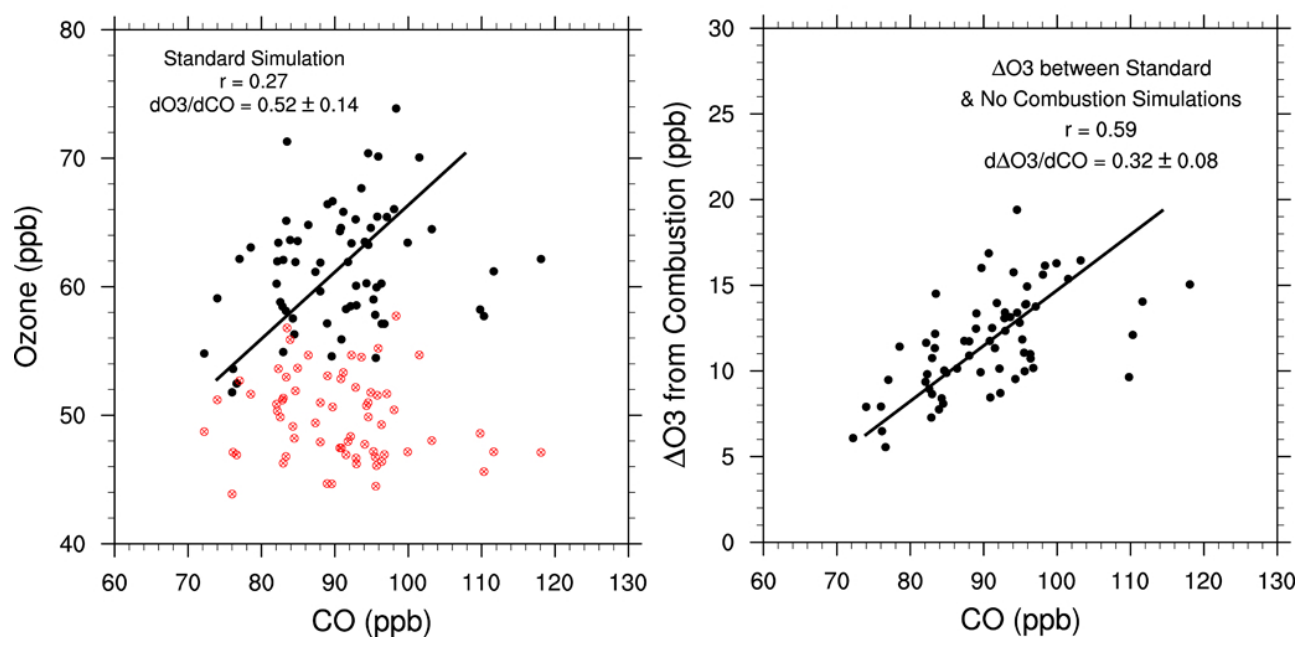

Fig. 5. Ozone-CO relationships at $700-400 \mathrm{hPa}$ in JJA 2008 over the western North Atlantic $\left(2^{\circ} \times 2.5^{\circ}\right.$ grid square centered at $38^{\circ} \mathrm{N}$, $70^{\circ} \mathrm{W}$ ). Values are GEOS-Chem model results sampled daily at the local OMI and AIRS satellite overpass times and weighted by the vertical sensitivity of the instruments. In the left panel, ozone concentrations in black are from the standard simulation and in red for the sensitivity simulation including no combustion sources. CO concentrations are from the standard simulation in both cases. The right panel shows the ozone difference $\Delta \mathrm{O}_{3}$ between the standard and sensitivity simulations as a function of CO from the standard simulation, with slope $d \Delta \mathrm{O}_{3} / d \mathrm{CO}$. All regression lines are obtained by the RMA method and the slope bound is the $95 \%$ confidence interval calculated from nonparametric bootstrapping.

influence of the source on ozone because the ozone-CO relationship is then affected by changes in both ozone and CO. A more appropriate approach is to correlate $\mathrm{CO}$ from the standard simulation with the ozone difference between the standard and sensitivity simulations. Chin et al. (1994) previously used this approach to interpret ozone-CO relationships from eastern North American surface sites in terms of ozone production.

We illustrate our approach in Fig. 5, which shows the simulated ozone-CO relationships at $700-400 \mathrm{hPa}$ for a $2^{\circ} \times 2.5^{\circ}$ grid square in JJA in the western North Atlantic $\left(38^{\circ} \mathrm{N}, 70^{\circ} \mathrm{W}\right)$ receiving polluted continental outflow from North America (Zhang et al., 2006, had previously examined the ozone-CO relationships observed from TES and aircraft for the same region). In the left panel in Fig. 5, ozone from the standard simulation is shown in black and ozone from a simulation without combustion sources is shown in red, both plotted against $\mathrm{CO}$ from the standard simulation. The ozone-CO slope and $95 \%$ confidence interval calculated using nonparametric bootstrapping for the standard simulation are shown inset. We see that the ozone-CO correlation disappears without combustion sources, indicating that it provides a test of combustion influence. This is quantified in the right panel by plotting the ozone difference $\Delta \mathrm{O}_{3}$ between the standard and no combustion simulations against $\mathrm{CO}$ from the standard simulation. We find a strong positive slope $d \Delta \mathrm{O}_{3} / d \mathrm{CO}$ that can explain the majority of $d \mathrm{O}_{3} / d \mathrm{CO}$ from the standard simulation.
Global maps of $d \Delta \mathrm{O}_{3} / d \mathrm{CO}$ for different ozone sources and seasons are presented in the supplementary material and can be used to interpret the $d \mathrm{O}_{3} / d \mathrm{CO}$ slopes in Fig. 2b. Here we focus our discussion on three illustrative regions of particular interest: (1) the North Atlantic in JJA $\left(30-40^{\circ} \mathrm{N}, 60-\right.$ $80^{\circ} \mathrm{W}$ ), where USA pollution outflow is known to take place and has been previously diagnosed from observed ozone-CO correlations; (2) the South Atlantic in DJF $\left(0-20^{\circ} \mathrm{S}, 30^{\circ} \mathrm{W}-\right.$ $10^{\circ} \mathrm{E}$ ), where different explanations have been proposed for the origin of the observed ozone maximum; and (3) the northeastern Pacific in SON $\left(20-40^{\circ} \mathrm{N}, 120-160^{\circ} \mathrm{W}\right)$, where significant intercontinental transport of Asian pollution is expected. As shown in Fig. 2b, GEOS-Chem reproduces the observed $d \mathrm{O}_{3} / d \mathrm{CO}$ from OMI/AIRS for (1) and (2) but fails for (3).

Figure 6 shows the observed and simulated $d \mathrm{O}_{3} / d \mathrm{CO}$ for the three above regions along with $d \Delta \mathrm{O}_{3} / d \mathrm{CO}$ calculated for simulations without combustion, biogenic, lightning $\mathrm{NO}_{\mathrm{x}}$, and stratospheric ozone sources for 2008. The statistics are calculated by aggregating all of the daily average ozone and $\mathrm{CO}$ data contained within the region's boundaries. We also include in Fig. 6 the observed $d \mathrm{O}_{3} / d \mathrm{CO}$ for 2006, along with model values for that year using both GEOS-5 and GEOS-4 meteorology. These allow us to examine interannual variability and the effect of transport errors as discussed above. Error bounds in Fig. 6 represent the standard deviation calculated from all nonparametric bootstrap slope realizations for each grid within the region's boundaries. 


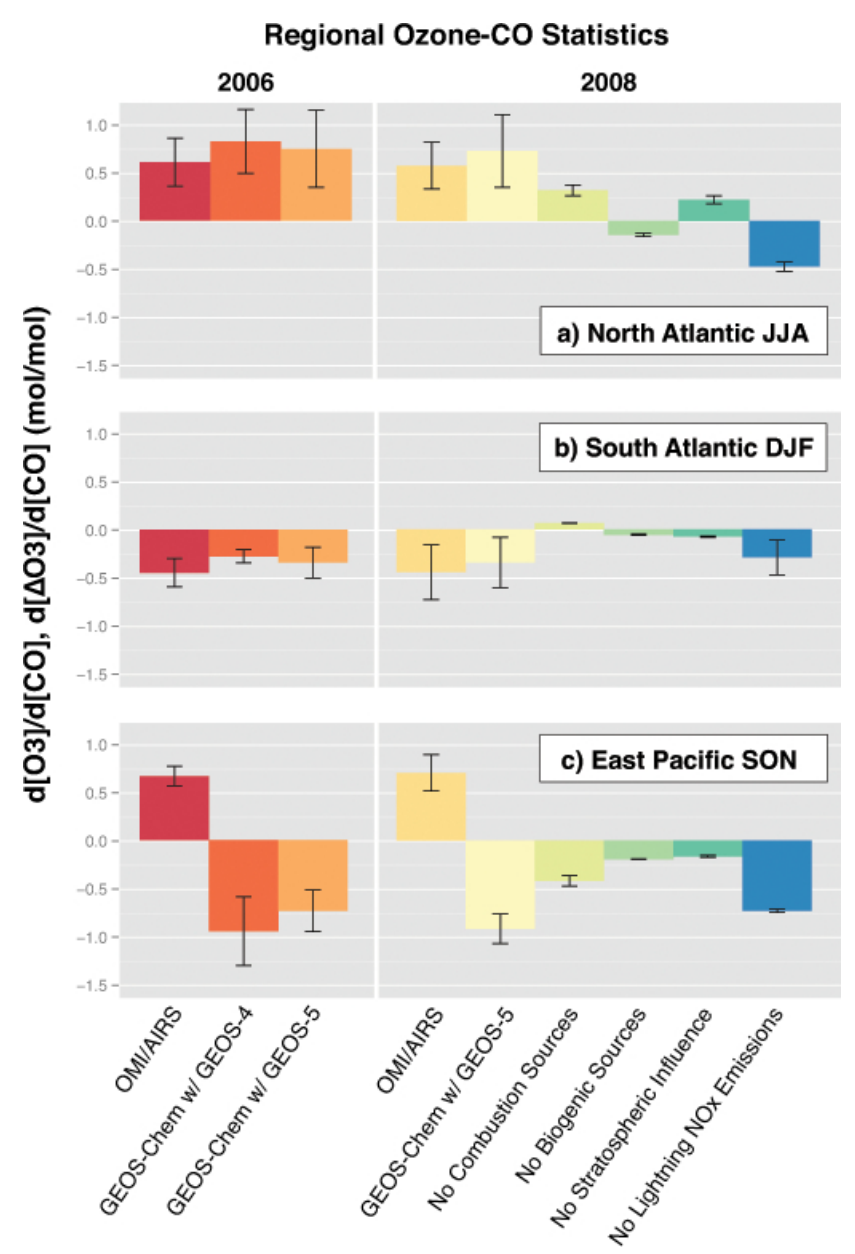

Fig. 6. Regional bar plots of ozone-CO statistics for (a) the western North Atlantic $\left(30-40^{\circ} \mathrm{N}, 60-80^{\circ} \mathrm{W}\right)$ in JJA; (b) the South Atlantic $\left(0-20^{\circ} \mathrm{S}, 30^{\circ} \mathrm{W}-10^{\circ} \mathrm{E}\right)$ in DJF; and (c) the eastern Pacific $\left(20-40^{\circ} \mathrm{N}, 120-160^{\circ} \mathrm{W}\right)$ in SON. From left to right, the bars show $d \mathrm{O}_{3} / d \mathrm{CO}$ for OMI/AIRS, GEOS-Chem driven by GEOS-4, and GEOS-Chem driven by GEOS-5 in 2006; $d \mathrm{O}_{3} / d \mathrm{CO}$ for OMI/AIRS and GEOS-Chem driven by GEOS-5 in 2008; and $d \Delta \mathrm{O}_{3} / d \mathrm{CO}$ for simulations without combustion sources, biogenic sources, stratospheric influence, and lightning $\mathrm{NO}_{\mathrm{x}}$ emissions for 2008. See text for explanation of error bounds.

\subsubsection{North Atlantic in JJA}

The observed ozone-CO relationship at northern midlatitudes in JJA shows a consistent positive correlation in continental outflow. Here we focus on the North Atlantic (Fig. 6a) but results are similar for the NW Pacific. The GEOS-Chem $d \mathrm{O}_{3} / d \mathrm{CO}$ agrees well with the observed slope of $0.72 \pm 0.30$ for 2008. The observed slopes show little difference between $2006(0.76 \pm 0.31)$ and 2008 . The GEOS-Chem results using GEOS-5 and GEOS-4 in 2006 are consistent, suggesting that the ozone-CO relationship is robust against errors in transport.
From the $d \Delta \mathrm{O}_{3} / d \mathrm{CO}$ values in Fig. 6a we see that the $\mathrm{O}_{3}-\mathrm{CO}$ correlation over the North Atlantic in JJA reflects a major contribution from combustion sources. Surface observations over the eastern USA in summer typically show a $d \mathrm{O}_{3} / d \mathrm{CO}$ value of $0.3-0.5$, with higher values in more recent studies reflecting a decrease in $\mathrm{CO}$ emissions (Chin et al., 1994; Hirsch et al., 1996; Mao and Talbot, 2004; Hudman et al., 2008, 2009). We find in our sensitivity simulation that $d \Delta \mathrm{O}_{3} / d \mathrm{CO}$ from combustion sources decreases from west to east across the North Atlantic while $d \mathrm{O}_{3} / d \mathrm{CO}$ remains roughly constant, suggesting little sustained photochemical production following lifting of the surface air to the free troposphere. The observed and simulated $d \mathrm{O}_{3} / d \mathrm{CO}$ fall within the range of slopes observed by Honrath et al. (2004) at a mountaintop site in the Azores for 2001 and 2003.

Air mixing down from the stratosphere makes a significant contribution to the ozone-CO regression slope, as shown in Fig. 6a. A remarkable result is that this effect is positive, whereas stratospheric influence is commonly thought to be associated with a negative ozone-CO correlation (Fishman and Seiler, 1983). As shown by Cooper et al. (2002), stratospheric influence over the western North Atlantic is associated with the dry air stream (DA) of midlatitude cyclones, mixing with the warm conveyor belt (WCB) that lifts continental pollution to the free troposphere. This would lead to positive correlation of pollution and stratospheric influences when smoothed vertically over the averaging kernel of the satellite observations. A number of studies have shown ozone pollution plumes over the northern midlatitude oceans to be interweaved with stratospheric influence (Parrish et al., 2000; Nowak et al., 2004; Price et al., 2004; Liang et al., 2007).

Lightning $\mathrm{NO}_{\mathrm{x}}$ has a large negative influence on $d \mathrm{O}_{3} / d \mathrm{CO}$ over the North Atlantic, comparable in magnitude to the positive influence from combustion sources (Fig. 6a). Lightning $\mathrm{NO}_{\mathrm{x}}$ produces both ozone and $\mathrm{OH}$ with high efficiency (Labrador et al., 2004), and $\mathrm{OH}$ oxidizes CO, thus leading in general to a negative $d \Delta \mathrm{O}_{3} / d \mathrm{CO}$ effect.

\subsubsection{South Atlantic in DJF}

Tropical tropospheric ozone shows a persistent maximum over the South Atlantic associated with strong subsidence (Thompson et al., 2000; Sauvage et al., 2006). The DJF ozone maximum is clearly seen by OMI (Fig. 1b) and is well reproduced by GEOS-Chem (Fig. S1b). The sources contributing to this maximum are not well understood. Different studies have argued for major contributions from combustion sources, including biomass burning in Africa (Thompson et al., 1996; Jourdain et al., 2007) and long-range transport of pollution (Chatfield et al., 2004), lightning $\mathrm{NO}_{\mathrm{x}}$ (Martin et al., 2002; Sauvage et al., 2007), and intrusions of northern hemispheric air (Waugh and Polvani, 2000; Martin et al., 2002).

We see in Fig. 6b that the observed regression slope for the region is negative with a value of $-0.49 \pm 0.31$. Good 
consistency is found between GEOS-Chem (either GEOS-5 or GEOS-4) and observations, and between 2006 and 2008. Model sensitivity studies indicate that the ozone-CO relationship is determined principally by lightning $\mathrm{NO}_{\mathrm{x}}$ emissions. This implies that the ozone variability in the region is driven by lightning as suggested previously by Sauvage et al. (2007). The negative ozone-CO correlation associated with the lightning $\mathrm{NO}_{\mathrm{x}}$ source reflects ozone production in the upper troposphere followed by strong subsidence of this photochemically aged air over the South Atlantic (Jacob et al., 1996; Martin et al., 2002). The $d \Delta \mathrm{O}_{3} / d \mathrm{CO}$ values in Fig. $6 \mathrm{~b}$ suggest that stratospheric and combustion sources, including biomass burning, make little contribution to the ozone maximum over the South Atlantic.

\subsubsection{Northeastern Pacific in SON}

The $d \mathrm{O}_{3} / d \mathrm{CO}$ values derived from OMI and AIRS are positive in all seasons over the northeastern Pacific poleward of $20^{\circ} \mathrm{N}$ (Fig. 2b). GEOS-Chem reproduces this in DJF and MAM, but has negative slopes in JJA that extend across the entire eastern North Pacific by SON. The SON discrepancy is summarized in Fig. 6c. A slope of $0.76 \pm 0.20$ is observed in 2008 (similar in 2006), but GEOS-Chem simulates a negative slope using either GEOS-5 or GEOS-4 meteorology. The consistency between GEOS-5 and GEOS-4 suggests that an error in sources is responsible for the poor simulation.

The model shows negative $d \Delta \mathrm{O}_{3} / d \mathrm{CO}$ over the region from all ozone sources including combustion (Fig. 6c). This is because air masses over the northeastern Pacific are very remote from sources, having been transported across the Pacific and subsiding slowly around the Pacific High. Ozone is produced efficiently in the subsiding air masses (Hudman et al., 2004; Zhang et al., 2008) while CO is oxidized. Figure 6c shows that lightning is the principal driver of the negative $d \mathrm{O}_{3} / d \mathrm{CO}$ values in GEOS-Chem.

Even in the absence of lightning influence, however, we see from Fig. $6 c$ that GEOS-Chem would still produce negative $d \mathrm{O}_{3} / d \mathrm{CO}$ values over the northeastern Pacific. This may reflect a model underestimate of $\mathrm{CO}$ emissions from East Asia, as supported by the underestimate of AIRS CO mixing ratios (compare Figs. 1a and S1a) and by the work of Kopacz et al. (2010), who found from an inverse analysis using AIRS CO data that GEOS-Chem underestimates CO sources in China by up to a factor of two in SON. Such a bias in $\mathrm{CO}$ emissions could cause the $d \Delta \mathrm{O}_{3} / d \mathrm{CO}$ values from Asian pollution over the northeastern Pacific to flip from positive to negative.

\section{Conclusions}

Ozone-CO correlations provide a valuable constraint to test models of tropospheric ozone but have hitherto been limited to in situ measurements and sparse satellite observations. By using satellite instruments with near-daily global coverage of the same scenes, OMI for ozone and AIRS for CO, we constructed a global data set of ozone-CO correlations in the free troposphere on a $2^{\circ} \times 2.5^{\circ}$ grid with seasonal resolution and for individual years. The high data density avoids the degradation of the correlations by instrument noise that was a problem in previous satellite studies. The correlation coefficients $r$ are highly significant, showing strong positive values in continental outflow in the northern extratropics. The tropics and Southern Hemisphere show seasonally varying patterns of positive and negative correlations. Evaluation with MOZAIC vertical profiles shows good consistency in correlation and regression slope patterns.

We interpreted the satellite-derived ozone-CO correlations with the GEOS-Chem chemical transport model to explore the constraints that they place on the model sources of ozone. By driving the model with different meteorological fields for the same year, we diagnosed the effect of model transport error on the correlations. This effect is large in some regions of the tropics, where the ozone-CO correlations are then of little value as a test of ozone sources. In general, however, we find that correlation patterns are consistent for different meteorological fields as well as different years, and can therefore be used as a test of ozone sources.

We tested the model sensitivity of the ozone-CO regression slope, $d \mathrm{O}_{3} / d \mathrm{CO}$, to different sources by conducting a series of sensitivity simulations with individual sources shut off (combustion, biosphere, stratosphere, lightning $\mathrm{NO}_{\mathrm{x}}$ ). From these we calculated the source influence, $d \Delta \mathrm{O}_{3} / d \mathrm{CO}$, by correlating the ozone change from each source with $\mathrm{CO}$ from the standard simulation. The results provide global information on the sources responsible for the ozone- $\mathrm{CO}$ correlations in the model, thus enabling interpretation of comparisons of simulated and observed $d \mathrm{O}_{3} / d \mathrm{CO}$. Complete results are in the supplementary materials. We focused our discussion on three regions of particular interest.

The northern extratropics show strong positive $d \mathrm{O}_{3} / d \mathrm{CO}$ in spring-summer that is driven by combustion sources and provides a test of the model simulation of continental outflow and intercontinental transport of ozone pollution. Remarkably, we find that stratospheric influence in the region is also associated with a positive $d \Delta \mathrm{O}_{3} / d \mathrm{CO}$ value, reflecting its interweaving with continental outflow.

The well-known tropical ozone maximum over the South Atlantic features a strongly negative $d \mathrm{O}_{3} / d \mathrm{CO}$, consistent for different years and meteorological data sets. GEOS-Chem reproduces this observation and attributes it to lightning. Previous model studies had reached a range of conclusions as to the origin of the South Atlantic ozone maximum, but the independent information from the ozone-CO correlations provides evidence of a dominant lightning source.

The northeastern Pacific is a region of particular interest for transpacific ozone pollution. Here we find that GEOSChem fails to reproduce the observed ozone-CO correlation in summer-fall, yielding negative $d \mathrm{O}_{3} / d \mathrm{CO}$ values when the 
observations show positive values. Remarkably, all ozone sources in the model yield negative $d \Delta \mathrm{O}_{3} / d \mathrm{CO}$ values in that region. This reflects the remote subsiding environment, where ozone is produced while $\mathrm{CO}$ is oxidized as air masses subside slowly around the Pacific High. Further analysis combined with independent evidence suggests that correcting this model bias would require both a reduction in the lightning source at northern midlatitudes and an increase in $\mathrm{CO}$ emissions in East Asia.

We have shown in this paper that the combination of OMI ozone and AIRS CO provides a robust global data set of ozone-CO correlations in the free troposphere, and that these correlations provide a powerful tool for testing ozone sources in global models. In future work we will exploit this data set further to examine interannual variability in ozone-CO correlations and the implications for our understanding of ozone sources.

\section{Supplementary material related to this article is available online at http://www.atmos-chem-phys.net/13/ 9321/2013/acp-13-9321-2013-supplement.pdf.}

Acknowledgements. This work was funded by the NASA Aura Program and in part by the Department of Energy Office of Science Graduate Fellowship Program (DOE SCGF), made possible in part by the American Recovery and Reinvestment Act of 2009, administered by ORISE-ORAU under contract no. DE-AC05-06OR23100. The authors acknowledge the support of the MOZAIC program by the European Commission, EADS, Airbus, and the airlines (Lufthansa, Austrian, Air France, and Air Namibia) who carry the MOZAIC equipment free of charge and who have performed the maintenance since 1994. The MOZAIC database is supported by ETHER (CNES and INSU-CNRS).

Edited by: J. Ma

\section{References}

Andreae, M. O., Anderson, B. E., Blake, D. R., Bradshaw, J. D., Collins, J. E., Gregory, G. L., Sachse, G. W., and Shipham, M. C.: Influence of plumes from biomass burning on atmospheric chemistry over the equatorial and tropical South Atlantic during CITE 3, J. Geophys. Res., 99, 12793-12808, doi:10.1029/94JD00263, 1994.

Aumann, H. H., Chahine, M. T., Gautier, C., Goldberg, M. D., Kalnay, E., McMillin, K. M., Revercomb, H., Rosenkranz, P. W., Smith, W. L., Staelin, D. H., Strow, L. L., and Susskind, J.: AIRS/AMSU/HSB on the Aqua Mission: Design, Science Objectives, Data Products, and Processing Systems, IEEE T. Geosci. Remote, 41, 253-264, doi:10.1109/TGRS.2002.808356, 2003.

Baray, J.-L., Duflot, V., Posny, F., Cammas, J.-P., Thompson, A. M., Gabarrot, F., Bonne, J.-L., and Zeng, G.: One year ozonesonde measurements at Kerguelen Island $\left(49.2^{\circ} \mathrm{S}, 70.1^{\circ} \mathrm{E}\right)$ : Influence of stratosphere-to-troposphere exchange and long-range transport of biomass burning plumes, J. Geophys. Res., 117, D06305, doi:10.1029/2011JD016717, 2012.

Beer, R., Glavich, T. A., and Rider, D. M.: Tropospheric emission spectrometer for the Earth Observing System's Aura satellites, Appl. Opt., 40, 2356-2367, doi:10.1364/AO.40.002356, 2001.

Bey, I., Jacob, D. J., Yantosca, R. M., Logan, J. A., Field, B., Fiore, A. M., Li, Q., Liu, H., Mickley, L. J., and Schultz, M.: Global modeling of tropospheric chemistry with assimilated meteorology: Model description and evaluation, J. Geophys. Res., 106, 23073-23096, doi:10.1029/2001JD000807, 2001.

Braak, R.: Bug fix for GDPS measurement noise calculation algorithm, KNMI, Technical Note TN-OMIE-KNMI-935, 2010.

Cardenas, L. M., Austin, J. F., Burgess, R. A., Clemitshaw, K. C., Dorling, S., Penkett, S. A., and Harrison, R. M.: Correlations between $\mathrm{CO}, \mathrm{NO}_{\mathrm{y}}, \mathrm{O}_{3}$, and non-methane hydrocarbons and their relationships with meteorology during winter 1993 on the north Norfolk coast, U.K., Atmos. Environ., 32, 3339-3351, doi:10.1016/S1352-2310(97)00445-7, 1998.

Chatfield, R. B., Guan, H., Thompson, A. M., and Witte, J. C.: Convective lofting links Indian Ocean air pollution to paradoxical South Atlantic ozone maxima, Geophys. Res. Lett., 31, L06103, doi:10.1029/2003GL018866, 2004.

Chin, M., Jacob, D. J., Munger, J. W., Parrish, D. D., and Doddridge, B. G.: Relationship of ozone and carbon monoxide over North America and its implication for ozone production and transport, J. Geophys. Res., 99, 14565-14573, doi:10.1029/94JD00907, 1994.

Cooper, O. R., Moody, J. L., Parrish, D. D., Trainer, M., Ryerson, T. B., Holloway, J. S., Hubler, G., Fehsenfeld, F. C., and Evans, M. J.: Trace gas composition of midlatitude cyclones over the western North Atlantic Ocean: A conceptual model, J. Geophys. Res., 107, D04056, doi:10.1029/2001JD000901, 2002.

Deeter, M. N., Emmons, L. K., Francis, G. L., Edwards, D. P., Gille, J. C., Warner, J. X., Khattatov, B., Ziskin, D., Lamarque, J.-F., Ho, S.-P., Yudin, V., Attie, J.-L., Packman, D., Chen, J., Mao, D., and Drummond, J. R.: Operational carbon monoxide retrieval algorithm and selected results for the MOPITT instrument, J. Geophys. Res., 108, 4399, doi:10.1029/2002JD003186, 2003.

Feng, L., Palmer, P. I., Yang, Y., Yantosca, R. M., Kawa, S. R., Paris, J.-D., Matsueda, H., and Machida, T.: Evaluating a 3-D transport model of atmospheric $\mathrm{CO}_{2}$ using ground-based, aircraft, and space-borne data, Atmos. Chem. Phys., 11, 27892803, doi:10.5194/acp-11-2789-2011, 2011.

Fiore, A. M., Dentener, F. J., Wild, O., Cuvelier, C., Schultz, M. G., Hess, P., Textor, C., Schulz, M., Doherty, R. M., Horowitz, L. W., MacKenzie, I. A., Sanderson, M. G., Shindell, D. T., Stevenson, D. S., Szopa, S., Van Dingenen, R., Zeng, G., Atherton, C., Bergmann, D., Bey, I., Carmichael, G., Collins, W. J., Duncan, B. N., Faluvegi, G., Folberth, G., Gauss, M., Gong, S., Hauglustaine, D., Holloway, T., Isaksen, I. S. A., Jacob, D. J., Jonson, J. E., Kaminski, J. W., Keating, T. J., Lupu, A., Marmer, E., Montanaro, V., Park, R. J., Pitari, G., Pringle, K. J., Pyle, J. A., Schroeder, S., Vivanco, M. G., Wind, P., Wojcik, G., Wu, S., and Zuber, A.: Multimodel estimates of intercontinental sourcereceptor relationships for ozone pollution, J. Geophys. Res., 114, D04301, doi:10.1029/2008JD010816, 2009. 
Fishman, J. and Seiler, W.: Correlative nature of ozone and carbon monoxide in the troposphere: implications for the tropospheric ozone budget, J. Geophys. Res., 88, 3662-3670, doi:10.1029/JC088iC06p03662, 1983.

Giglio, L., Randerson, J. T., van der Werf, G. R., Kasibhatla, P. S., Collatz, G. J., Morton, D. C., and DeFries, R. S.: Assessing variability and long-term trends in burned area by merging multiple satellite fire products, Biogeosciences, 7, 1171-1186, doi:10.5194/bg-7-1171-2010, 2010.

Guenther, A., Karl, T., Harley, P., Wiedinmyer, C., Palmer, P. I., and Geron, C.: Estimates of global terrestrial isoprene emissions using MEGAN (Model of Emissions of Gases and Aerosols from Nature), Atmos. Chem. Phys, 6, 3181-3210, doi:10.5194/acp-63181-2006, 2006.

Harris, J. M., Dlugokencky, E. J., Oltmans, S. J., Tans, P. P., Conway, T. J., Novelli, P. C., Thoning, K. W., and Kahl, J. D. W.: An interpretation of trace gas correlations during Barrow, Alaska, winter dark periods, 1986-1997, J. Geophys. Res., 105, 1726717278, doi:10.1029/2000JD900167, 2000.

Hegarty J. D., Mao, H., and Talbot, R.: Synoptic influences on springtime tropospheric $\mathrm{O}_{3}$ and $\mathrm{CO}$ over the North American export region observed by TES, Atmos. Chem. Phys., 9, 37553776, doi:10.5194/acp-9-3755-2009, 2009.

Hegarty J. D., Mao, H., and Talbot, R.: Winter- and summertime continental influences on tropospheric $\mathrm{O}_{3}$ and $\mathrm{CO}$ observed by TES over the western North Atlantic Ocean, Atmos. Chem. Phys., 10, 3723-3741, doi:10.5194/acp-10-3723-2010, 2010.

Hirsch, A. I., Munger, J. W., Jacob, D. J., Horowitz, L. W., and Goldstein, A. H.: Seasonal variation of the ozone production efficiency per unit $\mathrm{NO}_{\mathrm{x}}$ at Harvard Forest, Massachusetts, J. Geophys. Res., 101, 12659-12666, doi:10.1029/96JD00557, 1996.

Honrath, R. E., Owen, R. C., Val Martin, M., Reid, J. S., Lapina, K., Fialho, P., Dziobak, M. P, Kleissl, J., and Westphal, D. L.: Regional and hemispheric impacts of anthropogenic and biomass burning emissions on summertime $\mathrm{CO}$ and $\mathrm{O}_{3}$ in the North Atlantic lower free troposphere, J. Geophys. Res., 109, D24310, doi:10.1029/2004JD005147, 2004.

Hudman, R. C., Jacob, D. J., Cooper, O. R., Evans, M. J., Heald, C. L., Park. R. J., Fehsenfeld, F., Flocke, F., Holloway, J., Hubler, G., Kita, K., Koike, M., Kondo, Y., Neuman, A., Nowak, J., Oltmans, S., Parrish, D., Roberts, J. M., and Ryerson, T.: Ozone production in transpacific Asian pollution plumes and implications for ozone air quality in California, J. Geophys. Res., 109, D23S10, doi:10.1029/2004JD004974, 2004.

Hudman, R. C., Jacob, D. J., Turquety, S., Leibensperger, E. M., Murray, L. T., Wu, S., Gilliland, A. B., Avery, M., Bertram, T. H., Brune, W., Cohen, R. C., Dibb, J. E., Flocke, F. M., Fried, A., Holloway, J., Neuman, J. A., Orville, R., Perring, A., Ren, X., Sachse, G. W., Singh, H. B., Swanson, A., and Wooldridge, P. J.: Surface and lightning sources of nitrogen oxides over the United States: magnitudes, chemical evolution, and outflow, J. Geophys. Res., 112, D12S05, doi:10.1029/2006JD007912, 2007.

Hudman, R. C., Murray, L. T., Jacob, D. J., Millet, D. B., Turquety, S., Wu, S., Blake, D. R., Goldstein, A. H., Holloway, J., and Sachse, G. W.: Biogenic versus anthropogenic sources of CO in the United States, Geophys. Res. Lett., 35, L04801, doi:10.1029/2007GL032392, 2008.

Hudman, R. C., Murray, L. T., Jacob, D. J., Turquety, S., Wu, S., Millet, D. B., Avery, M., Goldstein, A. H., and Hol- loway, J.: North American influence on tropospheric ozone and the effects of recent emission reductions: Constraints from ICARTT observations, J. Geophys. Res., 114, D07302, doi:10.1029/2008JD010126, 2009.

IPCC: Climate Change 2007: The Physical Scientific Basis, Contribution of Working Group I to the Fourth Assessment Report of the Intergovernmental Panel on Climate Change, edited by: Solomon, S., Qin, D., Manning, M., Chen, Z., Marquis, M., Averyt, K. B., Tignor, M., and Miller, H. L., Cambridge University Press, Cambridge, United Kingdom and New York, NY, USA, 2007.

Jacob, D. J., Heikes, B. G., Fan, S.-M., Logan, J. A., Mauzerall, D. L., Bradshaw, J. D., Singh, H. B., Gregory, G. L., Talbot, R. W., Blake, D. W., and Sacshe, G. W.: Origin of ozone and $\mathrm{NO}_{\mathrm{x}}$ in the tropical troposphere: A photochemical analysis of aircraft observations over the South Atlantic basin, J. Geophys. Res., 101, 24235-24250, doi:10.1029/96JD00336, 1996.

Jaffe, D. A. and Wigder, N. L.: Ozone production from wildfires: A critical review, Atmos. Environ., 51, 1-10, doi:10.1016/j.atmosenv.2011.11.062, 2012.

Jourdain, L., Worden, H. M., Worden, J. R., Bowman, K., Li, Q., Eldering, A., Kulawik, S. S., Osterman, G., Boersma, K. F., Fisher, B., Rinsland, C. P., Beer, R., and Gunson, M.: Tropospheric vertical distribution of tropical Atlantic ozone observed by TES during the north African biomass burning season, Geophys. Res. Lett., 34, L04810, doi:10.1029/2006GL028284, 2007.

Kopacz, M. A., Jacob, D. J., Fisher, J. A., Logan, J. A., Zhang, L., Megretskaia, I. A., Yantosca, R. M., Singh, K., Henze, D. K., Burrows, J. P., Buchwitz, M., Khlystova, I., McMillan, W. W., Gille, J. C., Edwards, D. P., Eldering, A., Thouret, V., and Nedelec, P.: Global estimates of CO sources with high resolution by adjoint inversion of multiple satellite datasets (MOPITT, AIRS, SCIAMACHY, TES), Atmos. Chem. Phys., 10, 855-876, doi:10.5194/acp-10-855-2010, 2010.

Kuhns, H., Green, M., and Etyemezian, V.: Big Bend Regional Aerosol and Visibility Observational (BRAVO) Study Emissions Inventory, Report prepared for BRAVO Steering Committee, Desert Research Institute, Las Vegas, Nevada, 2003.

Labrador, L. J., von Kuhlmann, R., and Lawrence, M. G.: Strong sensitivity of the global mean $\mathrm{OH}$ concentration and the tropospheric oxidizing efficiency to the source of $\mathrm{NO}_{\mathrm{x}}$ from lightning, Geophys. Res. Lett., 31, L06102, doi:10.1029/2003GL019229, 2004.

Lee, C., Martin, R. V., van Donkelaar, A., Lee, H., Dickerson, R. R., Hains, J. C., Krotkov, N., Richter, A., Vinnikov, K., and Schwab, J. J.: $\mathrm{SO}_{2}$ emissions and lifetimes: Estimates from inverse modeling using in situ and global, space-based (SCIAMACHY and OMI) observations, J. Geophys. Res., 116, D06304, doi:10.1029/2010JD014758, 2011.

Levelt, P. F., van den Oord, G. H. J., Dobber, M. R., Malkki, A., Visser, H., de Vries, J., Stammes, P., Lundell, J. O. V., and Saari, H.: The Ozone Monitoring Instrument, IEEE T. Geosci. Remote, 44, 1093-1101, doi:10.1109/TGRS.2006.872333, 2006.

Liang, Q., Jaegle, L., Hudman, R. C., Turquety, S., Jacob, D. J., Avery, M. A., Browell, E. V., Sachse, G. W., Blake, D. R., Brune, W., Ren, X., Cohen, R. C., Dibb, J. E., Fried, A., Fuelberg, H., Porter, M., Heikes, B. G., Huey, G., Singh, H. B., and Wennberg, P. O.: Summertime influence of Asian pollution in the free troposphere over North America, J. Geophys. Res., 112, D12S11, 
doi:10.1029/2006JD007919, 2007.

Liu, J., Logan, J. A., Jones, D. B. A., Livesey, N. J., Megretskaia, I., Carouge, C., and Nedelec, P.: Analysis of $\mathrm{CO}$ in the tropical troposphere using Aura satellite data and the GEOS-Chem model: insight into transport characteristics of the GEOS meteorological products, Atmos. Chem. Phys., 10, 12207-12232, doi:10.5194/acp-10-12207-2010, 2010.

Liu, X., Bhartia, P. K., Chance, K., Spurr, R. J. D., and Kurosu, T. P.: Ozone profile retrievals from the Ozone Monitoring Instrument, Atmos. Chem. Phys., 10, 2521-2537, doi:10.5194/acp-10-25212010, 2010.

Mao, H. and Talbot, R.: $\mathrm{O}_{3}$ and $\mathrm{CO}$ relationships in New England: temporal variations and relationships, J. Geophys. Res., 109, D21304, doi:10.1029/2004JD004913, 2004.

Mao, J., Fan, S., Jacob, D. J., and Travis, K. R.: Radical loss in the atmosphere from $\mathrm{Cu}-\mathrm{Fe}$ redox coupling in aerosols, Atmos. Chem. Phys., 13, 509-519, doi:10.5194/acp-13-509-2013, 2013.

Marenco, A., Thouret, V., Nedelec, P., Smit, H., Helten, M., Kley, D., Karcher, F., Simon, P., Law, K., Pyle, J., Poschmann, G., Von Wrede, R., Hume, C., and Cook, T.: Measurement of ozone and water vapor by Airbus in-service aircraft: the MOZAIC airborne program, an overview, J. Geophys. Res., 103, 631-642, doi:10.1029/98JD00977, 1998.

Martin, R. V., Jacob, D. J., Logan, J. A., Bey, I., Yantosca, R. M., Staudt, A. M., Li, Q., Fiore, A. M., Duncan, B. N., Liu, H., Ginoux, P., and Thouret, V.: Interpretation of TOMS observations of tropical tropospheric ozone with a global model and in situ observations, J. Geophys. Res., 107, 4351, doi:10.1029/2001JD001480, 2002.

Martin, R. V., Sauvage, B., Folkins, I., Sioris, C. E., Boone, C., Bernath, P., and Ziemke, J.: Space-based constraints on the production of nitric oxide by lightning, J. Geophys. Res., 112, D09309, doi:10.1029/2006JD007831, 2007.

Mauzerall, D. L., Logan, J. A., Jacob, D. J., Anderson, B. E., Blake, D. R., Bradshaw, J. D., Heikes, B., Sachse, G. W., Singh, H. B., and Talbot, R. W.: Photochemistry in biomass burning plumes and implications for tropospheric ozone over the tropical south Atlantic, J. Geophys. Res., 103, 8401-8424, doi:10.1029/97JD02612, 1998.

McLinden, C. A., Olsen, S. C., Hannegan, B., Wild, O., Prather, M. J., and Sundet, J.: Stratospheric ozone in 3-D models: A simple chemistry and cross-tropopause flux, J. Geophys. Res., 105, 14653-14666, doi:10.1029/2000JD900124, 2000.

McMillan, W. W., Evans, K. D., Barnet, C. D., Maddy, E., Sachse, G. W., and Disken, G. S.: Validating the AIRS Version 5 CO retrieval with DACOM in situ measurements during INTEX-A and -B, IEEE T. Geosci. Remote, 49, 2802-2813, doi:10.1109/TGRS.2011.2106505, 2011.

McPeters, R. D., Labow, G. J., and Logan, J. A.: Ozone climatological profiles for satellite retrieval algorithms, J. Geophys. Res., 112, D05308, doi:10.1029/2005JD006823, 2007.

Monks, P. S.: A review of the observations and origins of the spring ozone maximum, Atmos. Environ., 34, 3545-3561, doi:10.1016/S1352-2310(00)00129-1, 2000.

Murray, L. T., Jacob, D. J., Logan, J. A., Hudman, R. C., and Koshak, W. J.: Optimized regional and interannual variability of lightning in a global chemical transport constrained by LIS/OTD satellite data, J. Geophys. Res., 117, D20307, doi:10.1029/2012JD017934, 2012.
Nowak, J. B., Parrish, D. D., Neuman, J. A., Holloway, J. S., Cooper, O. R., Ryerson, T. B., Nicks Jr., D. K., Flocke, F., Roberts, J. M., Atlas, E., de Gouw, J. A., Donnelly, S., Dunlea, E., Hubler, G., Huey, L. G., Schauffler, S., Tanner, D. J., Warneke, C., and Fehsenfeld, F. C.: Gas-phase chemical characteristics of Asian emission plumes observed during ITCT 2K2 over the eastern North Pacific Ocean, J. Geophys. Res., 109, D23S19, doi:10.1029/2003JD004488, 2004.

Olivier, J. G. J. and Berdowski, J. J. M.: Global emissions sources and sinks, in: The Climate System, edited by: Berdowski, J., Guicherit, R., and Heij, B. J., A. A. Balkema Publisher/Swets \& Zeitlinger Publishers, Lisse, the Netherlands, 33-78, 2001.

Parazoo, N. C., Denning, A. S., Kawa, S. R., Pawson, S., and Lokupitiya, R.: $\mathrm{CO}_{2}$ flux estimation errors associated with moist atmospheric processes, Atmos. Phys. Chem., 12, 6405-6416, doi:10.5194/acp-12-6405-2012, 2012.

Park, R. J., Jacob, D. J., Field, B. D., Yantosca, R. M., and Chin, M.: Natural and transboundary pollution influences on sulfate-nitrate-ammonium aerosols in the United States: implications for policy, J. Geophys. Res., 109, D15204, doi:10.1029/2003JD004473, 2004.

Parrish, D. D., Holloway, J. S., Trainer, M., Murphy, P. C., Forbes, F. L., and Fehsenfeld, F. C.: Export of North American pollution ozone to the North Atlantic Ocean, Science, 259, 1436-1439, doi:10.1126/science.259.5100.1436, 1993.

Parrish, D. D., Trainer, M., Holloway, J. S., Lee, J. E., Warshawsky, M. S., Fehsenfeld, F. C., Forbes, G. L., and Moody, J. L.: Export of North American ozone pollution to the North Atlantic Ocean, J. Geophys. Res., 103, 13357-13376, doi:10.1029/98JD00376, 1998.

Parrish, D. D., Holloway, J. S., Jakoubek, R., Trainer, M., Ryerson, T. B., Hubler, G., and Fehsenfeld, F. C.: Mixing of anthropogenic pollution with stratospheric ozone: A case study from the North Atlantic wintertime troposphere, J. Geophys. Res., 105, 2436324374, doi:10.1029/2000JD900291, 2000.

Price, H. U., Jaffe, D. A., Cooper, O. R., and Doskey, P. V.: Photochemistry, ozone production, and dilution during long-range transport episodes from Eurasia to the northwest United States, J. Geophys. Res., 109, D23S13, doi:10.1029/2003JD004400, 2004.

Rodgers, C. D.: Inverse method for atmospheric sounding: Theory and practice, World Sci., Hackensack, N. J., 2000.

Sauvage, B., Thouret, V., Thompson, A. M., Witte, J. C., Cammas, J.-P., Nedelec, P., and Athier, G.: Enhanced view of the "tropical Atlantic ozone paradox" and "zonal wave one" from the in situ MOZAIC and SHADOZ data, J. Geophys. Res., 111, D1, doi:10.1029/2005JD006241, 2006.

Sauvage, B., Martin, R. V., van Donkelaar, A., and Ziemke, J. R.: Quantification of the factors controlling tropical tropospheric ozone and the South Atlantic maximum, J. Geophys. Res., 112, D11309, doi:10.1029/2006JD008008, 2007.

Schneider, H. R., Jones, D. B. A., Shi, G. Y., and McElroy, M. B.: Analysis of residual mean transport in the stratosphere, 1. Model description and comparison with satellite data, J. Geophys. Res., 105, 19991-20011, doi:10.1029/2000JD900213, 2000.

Spurr, R. J. D.: VLIDORT: A linearized pseudo-spherical vector discrete ordinate radiative transfer code for forward model and retrieval studies in multilayer scattering media, J. Quant. Spectrosc. Ra., 102, 316-342, 2006. 
Stevenson, D. S., Dentener, F. J., Schultz, M. G., Ellingsen, K., van Noije, T. P. C., Wild, O., Zeng, G., Amann, M. Atherton, C. S., Bell, N., Bergmann, D. J., Bey, I., Butler, T., Cofala, J., Collins, W. J., Derwent, R. G., Doherty, R. M., Drevet, J., Eskes, H. J., Fiore, A. M., Gauss, M., Hauglustaine, D. A., Horowitz, L. W., Isaksen, I. S. A., Krol, M. C., Lamarque, J.-F., Lawrence, M. G., Montanaro, V., Muller, J.-F., Pitari, G., Prather, M. J., Pyle, J. A., Rast, S., Rodriguez, J. M., Sanderson, M. G., Savage, N. H., Shindell, D. T., Strahan, S. E., Sudo, K., and Szopa, S.: Multimodel ensemble simulations of present-day and near-future tropospheric ozone, J. Geophys. Res., 111, D08301, doi:10.1029/2005JD006338, 2006.

Susskind, J., Barnet, C. D., Blaisdell, J. M., Center, G. S. F., and Greenbelt, M. D.: Retrieval of atmospheric and surface parameters from AIRS/AMSU/HSB data in the presence of clouds, IEEE T. Geosci. Remote, 41, 390-409, doi:10.1109/TGRS.2002.808236, 2003.

Terao, Y., Logan, J. A., Douglass, A. R., and Stolarski R. S.: Contribution of stratospheric ozone to the interannual variability of tropospheric ozone in the northern extratropics, J. Geophys. Res., 113, D18309, doi:10.1029/2008JD009854, 2008.

Thompson, A. M., Pickering, K. E., McNamara, D. P., Schoeberl, M. R., Hudson, R. D., Kim, J. H., Browell, E. V., Kirchoff, V. W. J. H., and Nganga, D.: Where did tropospheric ozone over southern Africa and the tropical Atlantic come from in October 1992? Insights from TOMS, GTE TRACE A, and SAFARI 1992, J. Geophys. Res., 101, 24251-24278, doi:10.1029/96JD01463, 1996.

Thompson, A. M., Doddridge, B. G., Witte, J. C., Hudson, R. D., Luke, W. T., Johnson, J. E., Johnson, B. J., Oltmans, S. J., and Weiler, R.: A tropical Atlantic paradox: Shipboard and satellite views of a tropospheric ozone maximum and wave-one in January-February 1999, Geophys. Res. Lett., 27, 3317-3320, doi:10.1029/1999GL011273, 2000.

van der Werf, G. R., Randerson, J. T., Giglio, L., Collatz, G. J., Mu, M., Kasibhatla, P. S., Morton, D. C., DeFries, R. S., Jin, Y., and van Leeuwen, T. T.: Global fire emissions and the contribution of deforestation, savanna, forest, agricultural, and peat fires (19972009), Atmos. Chem. Phys., 10, 11707-11735, doi:10.5194/acp10-11707-2010, 2010.

van Donkelaar, A., Martin, R. V., Leaitch, W. R., Macdonald, A. M., Walker, T. W., Streets, D. G., Zhang, Q., Dunlea, E. J., Jimenez, J. L., Dibb, J. E., Huey, L. G., Weber, R., and Andreae, M. O.: Analysis of aircraft and satellite measurements from the Intercontinental Chemical Transport Experiment (INTEX-B) to quantify long-range transport of East Asian sulfur to Canada, Atmos. Chem. Phys. 8, 2999-3014, doi:10.5194/acp-8-2999-2008, 2008. van het Bolscher, M., Pereira, J., Spessa, A., Dalsoren, S., van Nojie, T., and Szopa, S.: REanalysis of the TROpospheric chemical composition over the past 40 years: A long-term global modeling study of tropospheric chemistry funded under the 5th EU framework programme, edited by: Schultz, M. and Rast, S., Rep. EVK2-CT-2002-00170, Max Planck Inst. for Meteorol., Hamburg, Germany, 1-77, 2008.

Vestreng, V. and Klein, H.: Emission data reported to UNECE/EMEP. Quality assurance and trend analysis and Presentation of WebDab, MSC-W Status Report 2002, Norwegian Meteorological Institute, Oslo, Norway, 2002.
Voulgarakis, A., Telford, P. J., Aghedo, A. M., Braesicke, P., Faluvegi, G., Abraham, N. L., Bowman, K. W., Pyle, J. A., and Shindell, D. T.: Global multu-year O3-CO correlation patterns from models and TES satellite observations, Atmos. Chem. Phys., 11, 5819-5838, doi:10.5194/acp-10-2491-2010, 2010.

Warner, J., Comer, M. M., Barnet, C. D., McMillan, W. W., Wolf, W., Maddy, E., and Sachse, G.: A comparison of satellite tropospheric carbon monoxide measurements from AIRS and MOPITT during INTEX-A, J. Geophys. Res., 112, D12S17, doi:10.1029/2006JD007925, 2007.

Warner, J. X., Wei, Z., Strow, L. L., Barnet, C. D., Sparling, L. C., Diskin, G., and Sachse, G.: Improved agreement of AIRS tropospheric carbon monoxide products with other EOS sensors using optimal estimation retrievals, Atmos. Chem. Phys., 10, 95219533, doi:10.5194/acp-10-9521-2010, 2010.

Waugh, D. W. and Polvani, L. M.: Climatology of Intrusions into the Tropical Upper Troposphere, Geophys. Res. Lett., 27, 38573860, doi:10.1029/2000GL012250, 2000.

Wild, O.: Modeling the global tropospheric ozone budget: exploring the variability in current models, Atmos. Chem. Phys., 7, 26432660, doi:10.5194/acp-7-2643-2007, 2007.

Wu, S., Mickley, L. J., Jacob, D. J., Logan, J. A., Yantosca, R. M., and Rind, D.: Why are there large differences between models in global budgets of tropospheric ozone?, J. Geophys. Res., 112, D05302, doi:10.1029/2006JD007801, 2007.

Yevich, R. and Logan, J. A.: An assesment of biofuel use and burning of agricultural waste in the developing world, Global Biogeochem. Cy., 17, 1095, doi:10.1029/2002GB001952, 2003.

Yurganov, L. N., McMillan, W. W., Dzhola, A. V., Grechko, E. I., Johnes, N. B., and van der Werf, G. R.: Global AIRS and MOPITT CO measurements: Validation, comparison, and links to biomass burning variations and carbon cycle, J. Geophys. Res., 113, D09301, doi:10.1029/2007JD009229, 2008.

Yurganov, L., McMillan, W., Grechko, E., and Dzhola, A.: Analysis of global and regional $\mathrm{CO}$ burdens measured from space between 2000 and 2009 and validated by ground-based solar tracking spectrometers, Atmos. Chem. Phys., 10, 3479-3494, doi:10.5194/acp-10-3479-2010, 2010.

Zahn, A., Brenninkmeijer, C. A. M., Asman, W. A. H., Crutzen, P. J., Heinrich, G., Fischer, H., Cuijpers, J. W. M., and van Velthoven, P. F. J.: Budgets of $\mathrm{O}_{3}$ and $\mathrm{CO}$ in the upper troposphere: CARIBIC passenger aircraft results 1997-2001, J. Geophys. Res., 107, 4337, doi:10.1029/2001JD001529, 2002.

Zhang, L., Jacob, D. J., Bowman, K. W., Logan, J. A., Turquety, S., Hudman, R. C., Li, Q., Beer, R., Worden, H. M., Worden, J. R., Rinsland, C. P., Kulawik, S. S., Lampel, M. C., Shephard, M. W., Fisher, B. M., Eldering, A., and Avery, M. A.: OzoneCO correlations determined by the TES satellite instrument in continental outflow regions, Geophys. Res. Lett., 33, L18804, doi:10.1029/2006GL026399, 2006.

Zhang, L., Jacob, D. J., Boersma, K. F., Jaffe, D. A., Olson, J. R., Bowman, K. W., Worden, J. R., Thompson, A. M., Avery, M. A., Cohen, R. C., Dibb, J. E., Flock, F. M., Fuelberg, H. E., Huey, L. G., McMillan, W. W., Singh, H. B., and Weinheimer, A. J.: Transpacific transport of ozone pollution and the effect of recent Asian emission increases on air quality in North America: an integrated analysis using satellite, aircraft, ozonesonde, and surface observations, Atmos. Chem. Phys., 8, 6117-6136, doi:10.5194/acp-8-6117-2008, 2008. 
Zhang, L., Jacob, D. J., Liu, X., Logan, J. A., Chance, K., Eldering, A., and Bojkov, B. R.: Intercomparison methods for satellite measurements of atmospheric composition: application to tropospheric ozone from TES and OMI, Atmos. Chem. Phys., 10, 4725-4739, doi:10.5194/acp-10-4725-2010, 2010.
Zhang, Q., Streets, D. G., Carmichael, G. R., He, K. B., Huo, H., Kannari, A., Klimont, Z., Park, I. S., Reddy, S., Fu, J. S., Chen, D., Duan, L., Lei, Y., Wang, L. T., and Yao, Z. L.: Asian emissions in 2006 for the NASA INTEX-B mission, Atmos. Chem. Phys., 9, 5131-5153, doi:10.5194/acp-9-5131-2009, 2009. 